\title{
Sosialisasi Penjernihan Air Baku Dengan Menggunakan Elektrokoagulasi Di SMP \& SMA Dr. Wahidin Sudirohusodo
}

\author{
Socialization Of Raw Water Purification By Using Electrocoagulation \\ In SMP \& SMA dr. Wahidin Sudirohusodo \\ Harlem Marpaung*, Rikson Siburian, Crystina Simanjuntak \\ Departemen Kimia, Fakultas Matematika dan Ilmu Pengetahuan Alam \\ Universitas Sumatera Utara \\ *Email: harlemmarpaung@gmail.com
}

\begin{abstract}
ABSTRAK
Telah dilakukan penelitian di salah satu SMP dan SMA Dr. Wahidin Sudirohusodo dengan menggunakan sampel air pada lokasi tersebut untuk penyerapan besi dengan metode eloktrolisis dengan menggunakan elektroda aluminium. Dengan menggunakan spektrofometri visible dan larutan seri standar $\mathrm{FeCl}_{3} .6 \mathrm{H}_{2} \mathrm{O}$ dapat diperoleh kandungan besi sebelum dilakukan eletrolisis, yakni sampel 1 $=2,5548 \mathrm{mg} / \mathrm{L}$ dan sampel $2=1,4458 \mathrm{mg} / \mathrm{L}$. Setelah dilakukan elektrolisis dan diukur kandungan besi dengan menggunakan spektrofotometri visible dan larutan seri standar $\mathrm{FeCl}_{3} .6 \mathrm{H}_{2} \mathrm{O}$, diperoleh hasil penyerapan besi pada sampel 1 sebesar $44,90 \%$ dan pada sampel 2 sebesar $21,84 \%$.
\end{abstract}

Kata Kunci: Aluminium, Elektroda, Elektrolisis, Spektrofotometri visible

\begin{abstract}
This Research has been done in one of Junior and Senior High Schools of Dr. Wahidin Sudirohusodo by using water samples at the site for iron absorption by electrolysis method using aluminum electrode. By using visible spectrophotometer and standard solution of $\mathrm{FeCl}_{3} \cdot 6 \mathrm{H}_{2} \mathrm{O}$ series can be obtained iron content before eletrolisis, ie $1=2.5548 \mathrm{mg} / \mathrm{L}$ and sample $2=1.4458 \mathrm{mg} / \mathrm{L}$. After electrolysis and measured iron content using visible spectrophotometry and standard solution of $\mathrm{FeCl}_{3} \cdot 6 \mathrm{H}_{2} \mathrm{O}$ series, iron absorption results obtained in sample 1 were $44.90 \%$ and in sample 2 were $21.84 \%$.
\end{abstract}

Keywords: Aluminum, Electrode, Electrolysis, Spectrophotometry visible 


\section{A. PENDAHULUAN}

Air merupakan sumber daya alam yang menjadi kebutuhan dasar bagi kehidupan. Dengan adanya air, semua makhluk hidup yang ada di bumi ini dapat tumbuh dan berkembang Air memiliki sekitar $75 \%$ berada pada permukaan bumi ini. Air banyak digunakan oleh manusia untuk tujuan bermacam-macam sehingga dengan mudah dapat tercemar. Beberapa bahan pencemar seperti bahan mikrobiologik (bakteri, virus, parasit), bahan organik (pestisida, detergen) dan beberapa bahan inorganik (garam,asam,logam), serta beberapa bahan kimia lainnya sudah banyak ditemukan dalam air yang kita pergunakan. (Darmono, 2001).

Peningkatan kebutuhan air bersih sebanding dengan perkembangan suatu daerah, maka eksploitasi air tanah juga semakin meningkat. Hal ini mengakibatkan persediaan akan air tanah menjadi semakin berkurang. Dan dengan berkurangnya kandungan air tanah pada lapisan akuifer dapat menyebabkan masuknya air laut kedalam akuifer. (Sosrodarsono, 2003).

Dalam melakukan usaha pengawasan yang diikuti dengan usaha pencegahan pencemaran air, harus dititikberatkan pada pengontrolan sumber pencemarannya. Ada dua bentuk sumber pencemar, yaitu sumber pencemar utama dan sumber pencemar lainnya. Sumber pencemar utama biasanya berasal dari sumber polusi yang menyebabkan pencemaran kadar tinggi, contohnya yaitu dari limbah pabrik. Sumber pencemar lainnya adalah sumber polusi dengan kadar pencemar relatif rendah yang berasal dari bermacam-macam sumber yang menyebar, misalnya dari lahan pertanian, rumah tangga, peternakan, dan sebagainya (Darmono, 2001).

Berdasarkan hasil wawancara dengan beberapa guru dan siswa yang berada di SMP \& SMA Dr. Wahidin Sudirohusodo Medan mengungkapkan keluhan-keluhan mengenai air sumur bor yang mereka gunakan selama ini. Dimana air sumur bor tersebut memilki sifat fisik yang kurang baik, hal ini dapat dibuktikan dengan warna air yang sangat keruh, berbau, dan rasanya yang payau. Ini dapat berdampak negatif terhadap guru-guru dan siswa-siswa yang memanfaatkan air tersebut sebagai air bersih dan biasa digunakan siswa-siswa untuk melakukan kegiatan sehari-hari. Maka hal ini harus dicegah dengan melakukan suatu perlakukan yang dapat mengurangi bau dan membuat warnanya menjadi jernih, dengan salah satu alat penyaring yang telah di desain untuk meningkatkan kualitas air sumur tersebut (diukur dengan beberapa parameter, seperti warna, bau, kekeruhan, $\mathrm{pH}$, dan lain sebagainya).

Tujuan penelitian ini adalah mengetahui metode yang tepat dalam penjernihan air baku dengan menggunakan elektokoagulasi di SMP \& SMA Dr. Wahidin Sudirohusodo. Manfaat pada penelitian, yaitu: Diperoleh metode yang tepat dalam penjernihan air baku dengan menggunakam elektrokoagulasi di SMP dan SMA Dr. Wahidin Sudirohusodo.

\section{B. METODOLOGI \\ Bahan dan Alat}

Bahan yang digunakan adalah: air sumur bor, $\mathrm{HNO}_{3(\mathrm{p})}$ dan Akuades. Sedangkan alat-alat yang digunakan pada penelitian, yaitu: Power Supply Apparatus, Elektroda Aluminium, Penjepit Buaya, Beaker Glass, Kabel Tunggal, Indikator Universal, Batang Pengaduk Kaca dan Statif dan Klem

\section{Pelaksanaan Penelitian \\ Pengambilan Sampel}

Sampel air sumur bor diambil dari SMP \& SMA Dr. Wahidin Sudirohusodo Medan kemudian ditambahkan asam nitrat pekat beberapan tetes lalu dimasukkan ke dalam wadah yang telah dibilas dengan akuades dan ditutup rapat.

\section{Pengujian dan Pengukuran Warna}

Sampel yang telah disiapkan dimasukkan kedalam beaker glass dan juga dengan blanko sebagai pembanding. Alat kolorimeter dihidupkan dan dibiarkan selama 15 menit. Kemudian blanko dan sampel dimasukkan begantian kedalam kuvet dan kemudian diukur.

\section{Suhu}

Sampel dimasukkan kedalam wadah yaitu beaker glass dan dimasukkan thermometer kedalamnya lalu diukur sampai konstan.

\section{Kekeruhan}

Sampel dimasukkan kedalam tabung pada nefelometer kemudian biarkan alat 
menunjukkan nilai pembacaan yang stabil dan catat nilai kekeruhan yang diamati.

pH

Sampel dimasukkan kedalam beaker glass kemudian dimasukkan alat pHmeter yang sebelumnya sudah di kalibrasi lalu dilakukan pengukuran sampai konstan

\section{Bau dan Rasa}

Pada pengujian Bau dilakukan secara organoleptik terhadap sampel yang dimasukkan kedalam beaker glass begitupun dengan rasa dilakukan secara langsung pada sampel air sumur bor.

\section{HASIL DAN PEMBAHASAN}

\section{Pembuatan Kurva Kalibrasi $\mathrm{FeCl}_{3} \cdot 6 \mathrm{H}_{2} \mathrm{O}$}

Data absorbansi yang diperoleh diplotkan terhadap konsentrasi larutan standar sehingga diperoleh kurva kalibrasi berupa garis linier seperti tautan pada gambar 1 berikut :

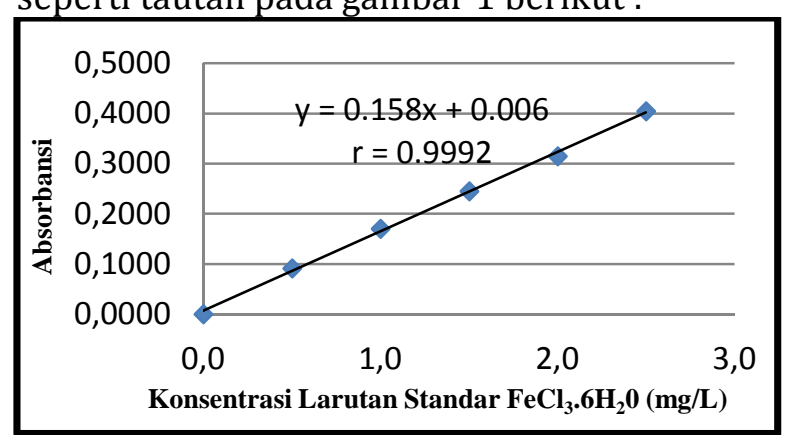

Gambar 1 Kurva Kalibrasi Larutan Seri Standar $\mathrm{FeCl}_{3} 6 \mathrm{H}_{2} \mathrm{O}$

\section{Konsentrasi Besi Sebelum dan Setelah dilakukan Elektrolisis}

Dari penelitian yang telah dilakukan diperoleh data konsentrasi besi sebelum dan setelah dilakukan elektrolisis dengan variasi elektroda seperti tautan pada Tabel 1 berikut:

Tabel 1 Konsentrasi Besi Sebelum dan Setelah dilakukan Elektrolisis di SMP dan SMA Dr. Wahidin Sudirohusodo.

\begin{tabular}{cccc}
\hline No & Kode Sampel & Absorbansi & $\begin{array}{c}\text { Konsentrasi Besi } \\
\text { (mg/L) }\end{array}$ \\
\hline 1. & $\mathrm{~A}$ & 0,411 & 2,5548 \\
2. & $\mathrm{~B}$ & 0,230 & 1,4076 \\
3. & $\mathrm{C}$ & 0.235 & 1,4458 \\
4. & $\mathrm{D}$ & 0.186 & 1,1300 \\
\hline
\end{tabular}

Keterangan Sampel:

A = Sampel Air SMP Dr. Wahidin Sudirohusodo

$\mathrm{B}=$ Setelah Elektrolisis dengan katoda Aliminium

C = Sampel Air SMA Dr. Wahidin Sudirohusodo

$\mathrm{D}=$ Setelah Elektrolisis dengan katoda Aluminium

\section{Persentase Penurunan Kadar Besi dengan Elektrolisis Menggunakan Elektroda Aluminium}

\section{a. SMPX}

Persentase penurunan kandungan besi dalam sampel air sumur sesudah dilakukan elektrolisis ditentukan dengan menggunakan persamaan berikut:

$\%$ Penyerapan $=$

$$
\frac{\text { Konsentrasi Awal - Konsentrasi Akhir }}{\text { Konsentrasi Awal }} \times 100 \%
$$

$$
\begin{aligned}
\% \text { Penyerapan } & =\frac{2,5548-1,4076}{2,5548} \times 100 \% \\
& =44,90 \%
\end{aligned}
$$

b. SMA Y

Persentase penurunan kandungan besi dalam sampel air sumur sesudah dilakukan elektrolisis ditentukan dengan menggunakan persamaan berikut:

$\%$ Penyerapan $=$

Konsentrasi Awal - Konsentrasi Akhir Konsentrasi Awal $-x 100 \%$

$$
\begin{aligned}
\% \text { Penyerapan } & =\frac{1,4458-1,1300}{1,4458} \times 100 \% \\
& =21,48 \%
\end{aligned}
$$

Dari hasil penelitian yang telah dilakukan dapat diambil kesimpulan bahwa penggunaan elektroda Aluminium sebagai katoda dan anoda memberikan hasil yang paling efektif.

\section{Perubahan Konsentrasi Besi terhadap Lama Waktu Elektrolisis}

Dari penelitian yang telah dilakukan diperoleh perubahan konsentrasi amonia terhadap lama waktu elektrolisis seperti tautan pada Gambar 2:

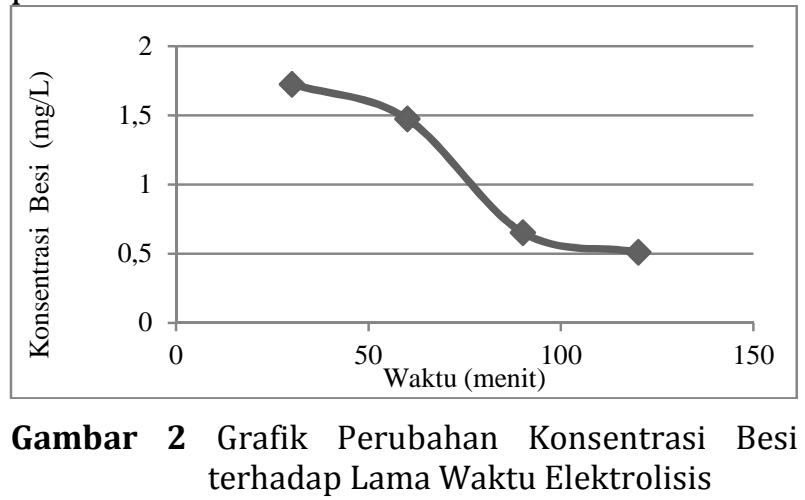

Dari Gambar 2, dapat diperoleh bahwa semakin lama waktu elektrolisis maka akan semakin besar pula penurunan kadar besi. Hal ini disebabkan karena semakin lama maka semakin banyak $\mathrm{Fe}^{3+}$ yang direduksi menjadi 
$\mathrm{Fe}^{2+}$. Dari hasil penelitian ini didapat waktu optimal dalam elektrolisis selama 90 menit.

\section{Perubahan Konsentrasi Besi terhadap Tegangan Listrik yang Diberikan}

Dari hasil penelitian yang telah dilakukan diperoleh perubahan konsentrasi besi terhadap tegangan listrik yang diberikan seperti tautan pada Gambar 3 berikut:

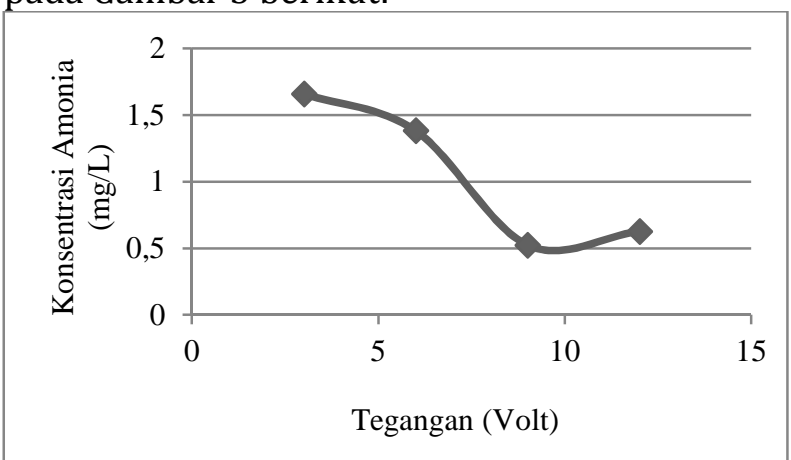

Gambar 3 Grafik Perubahan Konsentrasi Besi terhadap Tegangan Listrik yang diberikan Selama Elektrolisis

Dari gambar dapat diperoleh bahwa semakin besar tegangan yang diberikan selama elektrolisis maka akan semakin besar pula penurunan kadar besi. Pada gambar menunjukkan tegangan (voltase) optimum yang diperlukan sebesar 9 Volt. Hal ini dikarenakan tegangan arus listrik yang semakin tinggi menyebabkan elektroda melepaskan unsurunsur yang membantu penggumpalan. Dengan menggumpalnya bahan terlarut dalam air sumur maka akan terbentuk flok dan mengendap ke bawah ataupun mengapung pada bagian atas.

\section{KESIMPULAN}

Dari hasil penelitian yang telah dilakukan diperoleh kesimpulan sebagai berikut :

1. Konsentrasi besi sebelum dan setelah elektrolisis :

SMP Dr. Wahidin Sudirohusodo

- Sebelum elektrol

- isis $\quad: 2,5548 \mathrm{mg} / \mathrm{L}$

- Sesudah elektrolisis $\quad: 1,4076 \mathrm{mg} / \mathrm{L}$

SMA Dr. Wahidin Sudirohusodo

- Sebelum elektrolisis : $1,4458 \mathrm{mg} / \mathrm{L}$

- Sesudah elektrolisis : $1,1300 \mathrm{mg} / \mathrm{L}$

2. Persentase penurunan kadar besi dengan elektroda $\mathrm{Al}$ :

- SMP Dr. Wahidin Sudirohusodo: 44,90\%

- SMA Dr. Wahidin Sudirohusodo: 21,84\%
3. Dari hasil penelitian ini didapat waktu optimal dalam elektrolisis selama 90 menit.

4. Dari hasil penelitian ini didapat tegangan optimum dalam elektrolisis selama 9V.

\section{SARAN}

1. Penelitian ini masih merupakan dasar dari proses elektrolisis air untuk itu diperlukan penelitiannya selanjutnya melakukan penggunaan metode elektrolisis dalam pengelolaan berbagai limbah industri baik limbah industri kimia, pangan, tekstil, dan lain-lain.

2. Penelitian ini masih menggunakan elektroda Aluminium, untuk itu sangat diperlukan variasi penggunaan elektroda, $\mathrm{pH}$, waktu, dan tegangan.

\section{DAFTAR PUSTAKA}

Badan Standardisasi Nasional. Cara Uji Bau Pada Air. SNI 06-6860.80-2002.

Badan Standardisasi Nasional. Cara Uji Kekeruhan Dengan Metode Nefelometri. SNI 06-6989.25-2005.

Badan Standardisasi Nasional. Cara Uji $p H$ Menggunakan pHmeter. SNI 06-6989.112004.

Badan Standardisasi Nasional. Cara Uji Rasa Pada Air. SNI 06-6859-2002.

Badan Standardisasi Nasional. Cara Uji Suhu Menggunakan Thermometer. SNI 066989.23-2005.

Badan Standardisasi Nasional. Cara Uji Warna Secara Visual. SNI 06-6989.24-2005.

Darmono, 2001. Lingkungan Hidup dan Pencemaran Hubungannya dengan Toksikologi Senyawa Logam. Jakarta: UI Press.

Handoyo, 2014. Pencemaran Lingkungan. Yogyakarta: Gramedia Press

Situmorang, M. 2007. Kimia Lingkungan. Medan: Unimed Press

Sosrodarsono, S., dan K. Takeda, 2003. Hidrologi Untuk Pengairan. Pradnya Paramita, Jakarta.

Sunarya, Y. 2001. Pencemaran Air, Udara, Dan Tanah. Bandung: Grafindo Media Pratama. 